\title{
Nutritional intervention and functional exercises improve depression, loneliness and quality of life in elderly women with sarcopenia: a randomized clinical trial
}

\author{
Intervenção nutricional e exercícios funcionais melhoram \\ sintomas depressivos, de solidão e qualidade de vida de \\ idosas sarcopênicas: ensaio clínico randomizado
}

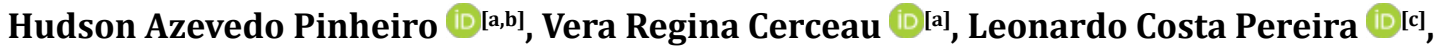 \\ Silvana Schwerz Funghetto ${ }^{[b]}$, Ruth Losada de Menezes $\left[{ }^{[b] *}\right.$ \\ [a] Secretaria Estadual de Saúde do Distrito Federal (SESDF), Brasília, DF, Brazil \\ [b] Universidade de Brasília (UnB), Brasília, DF, Brazil \\ [c] Centro Universitário Euro-Americano (UNIEURO), Brasília, DF, Brazil
}

\section{Abstract}

\begin{abstract}
Introduction: Loneliness interferes with the eating habits and functionality of the elderly, compromising their quality of life. Objective: This study aimed to evaluate the effects of eating and performing functional group-based exercises on depressive symptoms, loneliness and quality of life in patients with sarcopenia treated at a public health service. Method: This is a randomized clinical trial with a convenience sample of elderly women with sarcopenia according to the European Work Group of Sarcopenia on Older People (EWGSOP), divided into three groups of 20 subjects each: a control group (CG), functional exercise group (FEG), monitored using the Home-based Older People's Exercise (HOPE) program, and functional exercise and nutritional intervention group (NIG), which in addition to HOPE, received pre-training fruit juice (fast-absorbing carbohydrates) and post-training banana smoothie reinforced with peanut (leucine). These
\end{abstract}

\footnotetext{
*HAS: PhD, e-mail: hudsonap@gmail.com VRC: BS, e-mail: vrcerceau@gmail.com LCP: PhD, e-mail: leonardo.pcllcp@gmail.com SSF: PhD, e-mail: sivana.funghetto@gmail.com RLM: PhD, e-mail: ruthlosada@unb.br
} 
groups met twice a week for 12 weeks, the control group (CG) received health guidance at weekly meetings for 12 weeks. The results of the interventions were analyzed using the geriatric depression scale and UCLA loneliness scale, and quality of life using the EQ-5D. Results: Significant post-intervention differences were observed in the NIG group in depressive $(\mathrm{p}=0.008)$ and loneliness symptoms $(0.04)$ and quality of life (0.009), demonstrating the effects of group exercise and eating as a social activity. Conclusion: Nutritional intervention and functional group-based exercises were effective at minimizing depressive symptoms, social isolation, and improving the quality of life of elderly women with sarcopenia.

Keywords: Sarcopenia. Aged. Exercise Therapy. Loneliness. Quality of Life.

\section{Resumo}

Introdução: A solidão interfere na alimentação e funcionalidade de idosos comprometendo sua qualidade de vida. Objetivo: Analisar os efeitos da intervenção nutricional e exercícios funcionais nos sintomas depressivos, solidão e qualidade de vida de idosas sarcopênicas atendidas em serviço público de saúde. Método: Trata-se de ensaio clínico randomizado com amostra de conveniência, adotando os critérios do European Work Group of Sarcopenia on Older People (EWGSOP), em três grupos distintos com 20 idosas cada um: grupo de exercícios funcionais (GEF) que recebeu acompanhamento por meio do protocolo Home-based Older People's Exercises exercises (HOPE) e o grupo exercícios funcionais e intervenção alimentar (GEA), que além do HOPE recebia pré-treino por meio de suco de fruta integral (carboidratos de absorção rápida) e no pós-treino vitamina de banana acrescida de amendoim (leucina). Estes grupos se encontravam duas vezes por semana, por 12 semanas. $O$ grupo controle (GC) recebeu orientações de saúde em encontros semanais durante 12 semanas e os resultados das intervenções foram analisadas por meio da escala de depressão geriátrica, escala de solidão de UCLA e a qualidade de vida por meio do EQ-5D. Resultados: Foram observadas diferenças significativas quando comparou-se os grupos após a intervenção no grupo GEA tanto nos sintomas depressivos ( $p=0,008)$, solidão $(p=0,04)$ como na qualidade de vida $(p=0,009)$, demonstrando os efeitos tanto do exercício em grupo como do comer como atividade social. Conclusão: A intervenção nutricional e exercícios funcionais em grupo foram efetivos em minimizar os sintomas depressivos, isolamento social e melhorar a qualidade de vida em idosas sarcopênicas.

Palavras-chave: Sarcopenia. Envelhecimento. Terapia por Exercício. Solidão. Qualidade de Vida.

\section{Introduction}

Changes in family structure in recent years, primarily the number of children, combined with longer life expectancy in elderly Brazilians, have posed new challenges, such as loneliness. Older adults who live alone or spend most of their time alone exhibit greater decline in musculoskeletal functions, due to the decline in activities of daily living (ADL), mainly advanced and instrumental activities [1 - 3].

In addition to being a physiological need, the act of eating has social, economic, religious and psychological influences on the lives of individuals. Eating alone may exacerbate depressive symptoms in the elderly, who often eat inadequately, thereby increasing the risk of malnutrition, which has a direct impact on dysfunctions such as sarcopenia (age-related loss of muscle tissue) $[4,5]$.

Sarcopenia is a geriatric syndrome characterized by the generalized and progressive loss of muscle mass, associated with loss of muscle strength and/ or performance. It is associated with morbidities that affect quality of life, such as risk of falls, loss of autonomy, hospitalization and even death $[6,7]$.

Resistance training, associated with a proper diet, is a good option for managing sarcopenia in the elderly. However, economically underprivileged populations have limited access to fitness centers and 
professionals such as physiotherapists and physical education professors. They are generally restricted to Basic Health Units and/or Family Health Strategy teams, where group exercise has shown good results [8 - 13].

Given that physical exercise and adequate nutrition are protective factors for sarcopenia and personal factors interfere directly in adherence to any intervention, the aim of this study was to analyze the effects of nutritional intervention and group exercises on depressive symptoms, loneliness and quality of life in older adults with sarcopenia treated at a public health facility.

\section{Method}

A randomized clinical trial was conducted with a convenience sample recruited at a geriatric and gerontological outpatient facility at the Policlínica de Taguatinga (PCT), belonging to the Department of Health of the Federal District (SESDF), located 19 $\mathrm{km}$ from Brasilia, the capital of Brazil.

The study was approved by the Research Ethics Committee of the Health Education and Research Foundation of the Federal District, under process number 1.128.355/2015, and the experimental protocol was registered in the Brazilian clinical trials registry under process number REQ 3.616.

Included were women classified as sarcopenic according to the following criteria of the European Work Group of Sarcopenia on Older People (EWGSOP): low muscle mass, measured by calf circumference (CC), reduced muscle strength measured by grip strength (GS) and poor muscle performance, measured by gait speed (GT). Only women were chosen to participate for adherence-related reasons [6].

Excluded were subjects with amputation and seniors exhibiting neurological disease sequelae (cardiovascular disease, and parkinsonisms, among others), moderate-to-severe cognitive impairment, assessed using the Brazilian version of the MiniMental State Examination (MMSE) [14]. Also excluded were very active individuals, as defined by the Brazilian version of the physical activity index (PAI) [15].

In line with EWGSOP guidelines, calf circumference was measured in the most protruding region of the legs, with the subject sitting in a chair with her legs relaxed, using a nonelastic tape measure. Those who obtained measures less than or equal to $31 \mathrm{~cm}$ were considered at risk. Grip strength was determined using a JAMAR ${ }^{\circledR}$ dynamometer, adopting the protocol of the American Society of Hand Therapists for data acquisition. Three measures were taken of the dominant hand, one minute apart, and those with values below $20 \mathrm{~kg} / \mathrm{F}$ were considered sarcopenic. To measure GT, the senior walked on a flat surface, and the average velocity over three meters was calculated (according to Nakano), disregarding the acceleration and deceleration phase and dividing the distance walked by the time spent, with values of less than 0.8 $\mathrm{m} / \mathrm{s}$ indicating sarcopenia $[6,16]$.

\section{Sample selection}

Between September 2015 and July 2016, 90 women being treated at the nutritional and physiotherapy services who met EWGSOP sarcopenia criteria were invited to take part in the present study. They were randomly allocated to three groups by a blind examiner: functional exercise group (FEG), functional exercise and nutritional intervention group (NIG) and a control group (CG), between March and November 2016.

Initially, an interview was held to collect socioeconomic data and determine the degree of independence in activities of daily living (ADL) using the Barthel index [17]. Next, height and weight were measured on a Filizola ${ }^{\circledR}$ balance equipped with a stadiometer and used to calculate body mass index (BMI).

\section{Instruments used for assessment}

To assess depression indices, the Brazilian version of the geriatric depression scale (GDS) was used, composed of 15 items (short version) specially developed to detect mood disorders in older adults. The questions avoid addressing somatic complaints and offer valid and reliable measures for this purpose, where scores higher than five points indicate depressive symptoms [18].

Given the possible impacts of loneliness and isolation on the emergence and/or exacerbation of physical and emotional conditions in the elderly, the UCLA scale was selected. High scores indicate a risk of greater vulnerability and social exclusion, with those above 23 points denoting moderate loneliness, and higher than 48 points, intense loneliness, which 
compromises quality of life and functional capacity $[19,20]$.

Finally, the EQ-5D, developed by the EuroQol group, was applied to measure quality of life, using the following five domains: mobility, personal care, daily activities, pain and anxiety, with each domain varying between 1 and 3 points. The higher the score, the worse the quality of life, with scores above 10 points indicating poor quality of life [21].

\section{Intervention}

The protocol for the FEG was based on the Homebased Older People's Exercise (HOPE) program, developed by Clegg et al. (2010) for frail elderly. The Timed Up and Go (TUG) test was applied to assess functional activities using progressive resistance training. In order to ensure greater adherence, exercises were conducted in groups and supervised by a duly trained physiotherapist, twice a week for 12 weeks $[12,13]$.

The NIG was submitted to the same training characteristics and frequency as the FEG. However, given that the muscular hypertrophy process depends on nutritional status, a nutritionist delivered a lecture on the topic, encouraging protein intake of 20 to $35 \%$ of total calories, since the presence of essential amino acids, primarily leucine, may enhance anabolic potential, influencing the protein synthesis needed to increase muscle mass $[22,23]$.

To ensure that no muscle loss occurred during the intervention period, since the elderly's diets were not controlled at home, they were given a pre-training snack consisting of a $200 \mathrm{~mL}$ glass of natural fruit juice (orange or grape) in order to provide fast-absorbing carbohydrates, and a post-training $200 \mathrm{~mL}$ banana or avocado smoothie containing whole milk and added with peanut. Supervised by a nutritionist, the subjects sat at a table and were free to discuss any subject while eating, until all had finished their meal $[24,25]$.

The CG met once a week for twelve weeks, attending informational lectures on successful aging and prevention of social isolation. These encounters were planned based on the Ministry of Health's basic care supplement, described in Table 1 [26]. During the study, the group was guided by an occupational therapist or psychologist [27] and did not take part in any physical training or nutritional intervention protocol.
Table 1 - Control group activities

\begin{tabular}{ll}
\hline Meeting & \multicolumn{1}{c}{ Topic } \\
1 & $\begin{array}{l}\text { Getting to know each other; } \\
\text { Friendship and self-efficacy. }\end{array}$ \\
2 and 3 & $\begin{array}{l}\text { Healthy nutrition: nutrients and their functions, } \\
\text { hydration; } \\
\text { Preparing a healthy meal. }\end{array}$ \\
4 and 5 & $\begin{array}{l}\text { Preventing falls: removing home hazards, } \\
\text { adequate footwear. }\end{array}$ \\
6 and 7 & $\begin{array}{l}\text { Falling: How to fall and how to get up. } \\
8 \text { and } 9\end{array}$ \\
8 and 9 & $\begin{array}{l}\text { Activities of daily living: removing home hazards } \\
\text { and maing the necessary adjustments to }\end{array}$ \\
& $\begin{array}{l}\text { Family conflicts. } \\
12\end{array}$ \\
\hline
\end{tabular}

\section{Statistical analysis}

The SPSS statistical package, version 22.0, was used for statistical calculations. The results of continuous variables were expressed as mean and standard deviation. The Shapiro-Wilk test was conducted to verify data normality and the Student's t-test and ANOVA post-hoc to compare results. The effect size and study power were also assessed using Gpower software, version 3.1, obtaining 1.31 and 0.8 , respectively.

\section{Results}

The 60 elderly women were divided into three groups of 20 each. However, during the 12-week intervention, sample losses occurred due to the poor evolution of a femoral fracture (one), distal radius and ulnar fracture (one), pain with functional worsening (three), nasogastric intubation due to functional decline (one), international travel (one) and the remainder owing to socioeconomic and family issues, resulting in 10 seniors in the FEG, nine in the NIG and 11 in the CG.

With respect to the elderly that completed the intervention, the average age was $80.3 \pm 6.8$ years, all with at least five years of schooling and independent for ADL. No intergroup differences were observed (Table 2). 
Table 2 - Sample characterization

\begin{tabular}{|c|c|c|c|c|c|}
\hline Variable & & FEG & NIG & CG & $p$ \\
\hline Concluded & & 10 & 9 & 11 & $0.98^{£}$ \\
\hline \multirow[t]{2}{*}{ EWGSOP } & Sarcopenia & 5 & 7 & 8 & \multirow{2}{*}{$0.26^{£}$} \\
\hline & Severe sarcopenia & 5 & 2 & 3 & \\
\hline \multirow[t]{2}{*}{$\begin{array}{l}\text { Stable } \\
\text { relationship }\end{array}$} & Yes & 3 & 1 & 1 & \multirow[t]{2}{*}{$0.25^{2}$} \\
\hline & $\begin{array}{l}\leq 2 \text { minimum } \\
\text { monthly }\end{array}$ & 6 & 1 & 8 & \\
\hline Family income ${ }^{c}$ & $\begin{array}{l}>3 \text { minimum } \\
\text { monthly wages }\end{array}$ & 4 & 8 & 3 & 0.14 \\
\hline Age & & $79 \pm 7.66$ & $78.67 \pm 5.63$ & $81.7 \pm 5.95$ & $0.36^{£}$ \\
\hline BMI $\left(\mathrm{cm} / \mathrm{kg}^{2}\right)$ & & $23.1 \pm 4.1$ & $21.9 \pm 2.9$ & $22.8 \pm 1.8$ & $0.47^{£}$ \\
\hline $\begin{array}{l}\text { Barthel index } \\
\text { (points) }\end{array}$ & & $95.5 \pm 3.7$ & $96.4 \pm 6.1$ & $96.6 \pm 4.1$ & $0.98^{£}$ \\
\hline
\end{tabular}

Note: $\mathrm{FEG}=$ functional exercise group; $\mathrm{NIG}=$ functional exercise and nutritional intervention group; $\mathrm{CG}=$ control group; $\mathrm{EWGSOP}=\mathrm{Eu}-$ ropean Work Group on Sarcopenia in Older People; BMI= body mass index; ‘Minimum monthly wage in Brazil in 2016 was BRL 880.00 $(\approx$ USD228.00); ₹ Student's t-test.

A comparison between pre- and post-interin GED, UCLA and EQ-5D only in the NIG, as shown vention results shows significant improvements in Table 3.

Table 3 - Comparison between pre- and post-intervention psychosocial variables

\begin{tabular}{lcccccc}
\hline & FEG & $\mathbf{p}$ & NIG & $\mathbf{p}$ & $\mathbf{C G}$ & $\mathbf{p}$ \\
Pre GDS & $4.55 \pm 2.94$ & & $10.88 \pm 2.95$ & & $4.4 \pm 3.13$ & \\
Post GDS & $4.18 \pm 3.16$ & $0.31^{\varepsilon}$ & $6.63 \pm 2.07$ & $0.008^{£ \star}$ & $4.5 \pm 3.34$ & $0.15^{£}$ \\
Pre UCLA & $10.91 \pm 6.92$ & & $5.38 \pm 3.16$ & & $10.9 \pm 7.94$ & \\
Post UCLA & $10.91 \pm 9.04$ & $0.71^{\varepsilon}$ & $3.5 \pm 2$ & $0.04^{£ \star *}$ & $11.3 \pm 8.58$ & $0.31^{\varepsilon}$ \\
Pre EQ-5D & $6.91 \pm 1.64$ & & $6.75 \pm 0.46$ & & $7.5 \pm 1.72$ & \\
Post EQ-5D & $6.55 \pm 1.29$ & $0.11^{\varepsilon}$ & $5.38 \pm 0.52$ & $0.009^{£ *}$ & $7.4 \pm 1.58$ & $0.31^{\varepsilon}$ \\
\hline
\end{tabular}

Note: $\mathrm{FEG}=$ functional exercise group; $\mathrm{NIG}=$ functional exercise and nutritional intervention group; $\mathrm{CG}=$ control group; $\mathrm{GDS}=$ geriatric depression scale; UCLA $=$ UCLA Ioneliness scale; $\mathrm{EQ}-5 \mathrm{D}=$ Euroqol; ${ }^{\circledR}=$ ANOVA post hoc; ${ }^{\star} \mathrm{p}<0.01 ;{ }^{\star \star} \mathrm{p}<0.05$.

\section{Discussion}

The study demonstrated that nutritional intervention associated with functional group-based exercise was more effective than only functional exercises or socialization activities in seniors with sarcopenia.

Literature studies recommend home exercise programs as a strategy to preserve functional capacity in community-dwelling elderly, particularly pre-sarcopenic and sarcopenic individuals. However, in Western countries, there is a culture of regular physical activity as an important element for well-being and quality of life in the aging process. Therapeutic group activities are needed in order to optimize adherence, mainly in developing countries [28 - 30].

An Iranian study assessed the effects of physical activity on the functional capacity and mental health of older adults, monitoring two different groups, one engaged in a home-based exercise program and the other a group that met twice a week. Both groups exhibited improvements in functional capacity domains; however, those engaged in group exercises obtained better scores in perceived overall health and depressive symptoms [31]. These findings corroborate those of the present 
study, which found gains in functional capacity and mental health-related psychosocial aspects, primarily in depression and quality of life, given that the seniors exercising in a group no longer felt isolated.

Recent studies have demonstrated the impact of sarcopenia on depression and quality of life, confirming it as an important risk factor since muscle strength and physical performance limitations have a direct relation with the ability to perform ADL, especially the advanced and instrumental activities conducted outside the home. As such, sarcopenia diminishes the mobility of older people, who remain homebound, contributing to their isolation, thereby worsening depressive symptoms and quality of life [3, 32 - 34].

In the present study, in order to ensure the proper execution of the exercises proposed, the group did not exercise only at home, since going out is stimulating, especially for the self-esteem and vanity of the women studied here, demonstrating a significant effect on the variables assessed.

Another aspect observed in the present study occurred in the NIG, where the elderly participants dined together before and after the exercises. Family relations were discussed, bonds of friendships were established, feelings of solidarity were manifested and depression improved, as did quality of life, after the interventions.

In addition to being a physiological need, eating is a social act engaged in since early childhood, where behaviors, exchange of experiences, and cultural rites are presented, performed and repeated, bringing people together and having a direct impact on quality of life. Many older adults spend considerable time alone at home, where women have no desire to cook, resulting in their eating leftovers or low-nutrient food, contributing as a risk factor for sarcopenia $[4,35,36]$.

Studies have shown the positive effects of eating with others, especially with respect to mood and loneliness-related aspects, in addition to insecurities and food taboos [5,36 - 38]. These findings corroborate those of the present study.

Loneliness is an emerging geriatric syndrome that contributes significantly to worsening functional capacity, given that it leads to a progressive decline in physical mobility and food consumption and a rise in depressive symptoms, risk of falls, and fear of falling, all of which lower quality of life $[1,2,39,40]$.

Guimarães et al. [41] investigated the effect of physical activity on quality of life and the perception of its inevitable decline, and found that the possibility of becoming dependent with age is a worrisome factor, expressed in the following common discourse: it is better to die young than to feel the anguish and loneliness of old age because of fear of physical infirmity. As such, physical activity has a positive impact on preserving functional capacity and improving quality of life [41].

Merquiades et al. found that older adults engaged in regular physical activity obtained better results in terms of health problems and above all, quality of life. These findings corroborate those of the present study, where perceived quality of life was better in those who exercised regularly [42].

The literature has demonstrated the benefits of including health professionals such as physiotherapists and nutritionists in basic health units (BHU) for quality of life and longevity. This represents an investment that enhances functional health indicators and may reverse the adverse symptoms of disease through health orientation and group therapy, which generate social bonds and could contribute to a lower risk of comorbidities $[43,44]$.

Study limitations include the failure to control elderly food intake at home and analyze family support for these individuals. Another limitation was not comparing with other similar studies involving functional exercises, eating habits, non-supplementation and social and emotional issues in the context of public health, suggesting the need for new research in the area.

\section{Conclusion}

Nutritional intervention and group-based functional exercises were effective in minimizing depressive symptoms and social isolation and enhancing the quality of life of older adults with sarcopenia treated at a public health facility.

\section{References}

1. Buchman AS, Boyle PA, Wilson RS, James BD, Leurgans SE, Arnold SE, et al. Loneliness and the rate of motor decline in old age: the rush memory and aging project, a community-based cohort study. BMC Geriatr. 2010;10(1):77. 
2. Pereira RJ, Cotta RMM, Franceschini SCC, Ribeiro RCL, Sampaio RF, Priore SE, et al. Contribuição dos domínios físico, social, psicológico e ambiental para a qualidade de vida global de idosos. Rev Psiquiatr Rio Gd Sul. 2006;28(1):27-38.

3. Dias EG, Duarte YAO, Almeida MHM, Lebrão ML. Caracterização das atividades avançadas de vida diária (AAVDS): um estudo de revisão. Rev Ter Ocup. 2011;22(1):45-51.

4. Locher JL, Ritchie CS, Robinson CO, Roth DL, Smith West D, Burgio KL. A multidimensional approach to understanding under-eating in homebound older adults: the importance of social factors. Gerontologist. 2008;48(2):223-34.

5. Kuroda A, Tanaka T, Hirano H, Ohara Y, Kikutani T, Furuya $\mathrm{H}$, et al. Eating Alone as Social Disengagement is Strongly Associated with Depressive Symptoms in Japanese Community-Dwelling Older Adults. J Am Med Dir Assoc. 2015;16(7):578-85.

6. Cruz-Jentoft AJ, Baeyens JP, Bauer JM, Boirie Y, Cederholm T, Landi F, et al. Sarcopenia: European consensus on definition and diagnosis: Report of the European Working Group on Sarcopenia in Older People. Age Ageing. 2010;39(4):412-23.

7. Muscaritoli M, Anker SD, Argilés J, Aversa Z, Bauer JM, Biolo G, et al. Consensus definition of sarcopenia, cachexia and pre-cachexia: Joint document elaborated by Special Interest Groups (SIG) "cachexia-anorexia in chronic wasting diseases" and "nutrition in geriatrics". Clin Nutr. 2010;29(2):154-9.

8. Reid KF, Callahan DM, Carabello RJ, Phillips EM, Frontera WR, Fielding RA. Lower extremity power training in elderly subjects with mobility limitations: a randomized controlled trial. Aging Clin Exp Res. 2008;20(4):337-43.

9. Galvão DA, Taaffe DR. Resistance exercise dosage in older adults: Single- versus multiset effects on physical performance and body composition. J Am Geriatr Soc. 2005;53(12):2090-7.

10. Lustosa LP, Coelho FM, Silva JP, Pereira DS, Parentoni AN, Dias JMD, et al. The effects of a muscle resistance program on the functional capacity, knee extensor muscle strength and plasma levels of IL- 6 and TNF-alpha in prefrail elderly women: a randomized crossover clinical trial--a study protocol. Trials. 2010;11:82.
11. Facchini LA, Tomasi E. Assistência domiciliar a idosos: fatores associados, características do acesso e do cuidado Home health care for the elderly: associated factors and characteristics of access and health care. Rev Saude Publica. 2010;44(6):1102-11.

12. Clegg A, Barber S, Young J, Forster A, Iliffe S. The HomeBased Older People's Exercise (HOPE) trial: study protocol for a randomised controlled trial. Trials. 2011;12:143.

13. Clegg A, Barber S, Young J, Iliffe S, Forster A. The Homebased Older People's Exercise (HOPE) trial: A pilot randomised controlled trial of a home-based exercise intervention for older people with frailty. Age Ageing. 2014;43(5):687-95.

14. Veras RP. Mini-Exame do Estado Mental : características psicométricas em idosos ambulatoriais. Rev Saude Publica. 2006;40(4):712-9.

15. Matsudo S, Araújo T, Matsudo V, Andrade D, Andrade E, Oliveira LC, et al. Questionário Internacional de Atividade Física (Ipaq): Estupo de validade e reprodutibilidade no Brasil. Rev Bras Ativ Fis Saude. 2012;6(2):5-18.

16. Nakano M. Versão brasileira da Short Physical Performance Battery - SPPB: adaptação cultural e estudo da confiabilidade [dissertation]. Campinas: Universidade Estadual de Campinas; 2007.

17. Minosso JSM, Amendola F, Alvarenga MRM, Oliveira MAC. Validação, no Brasil, do Índice de Barthel em idosos atendidos em ambulatórios. Acta Paul Enferm. 2010;23(2):218-23.

18. Irigaray TQ Schneider RH. Prevalência de depressão em idosas participantes da Universidade para a Terceira Idade. Rev Psiquiatr Rio Gd Sul. 2007;29(1):19-27.

19. Barroso SM, Midgett AH, Gomes R, Carvalho N. Evidências de validade da Escala Brasileira de Solidão UCLA Evidence of validity of Brazilian UCLA Loneliness Scale. J Bras Psiquiatr. 2016;65(1):68-75.

20. Barroso SM, Andrade VS, Oliveira NR. Escala Brasileira de Solidão: Análises de Resposta ao Item e definição dos pontos de corte. J Bras Psiquiatr. 2016;65(1):76-81.

21. Ferreira PL, Ferreira LN, Pereira LN. Contribution for the validation of the Portuguese version of EQ-5D. Acta Med Port. 2013;26(6):664-75. 
22. Rogero MM, Tirapegui J. Aspectos atuais sobre aminoácidos de cadeia ramificada e exercício físico. Rev Bras Cienc Farm. 2008;44(4):563-75.

23. Bauer J, Biolo G, Cederholm T, Cesari M, Cruz-Jentoft AJ, Morley JE, et al. Evidence-based recommendations for optimal dietary protein intake in older people: A position paper from the prot-age study group. J Am Med Dir Assoc. 2013;14(8):542-59.

24. Goldenberg M. Cultura e gastro-anomia: psicopatologia da alimentação cotidiana. Entrevista com ClaudeFischler. Horiz Antropol. 2011;17(36):235-56.

25. Kukuljan S, Nowson CA, Sanders K, Daly RM. Effects of resistance exercise and fortified milk on skeletal muscle mass , muscle size, and functional performance in middle-aged and older men: an 18-mo randomized controlled trial. J Appl Physiol. 2009;107(6):1864-73.

26. Brasil. Ministério da Saúde. Secretaria de Atenção à Saúde. Departamento de Atenção Básica. Envelhecimento e saúde da pessoa idosa. Brasília: Ministério da Saúde; 2006. 192 p.

27. Cilento MBR, Nóbrega ACL. Avaliação da eficácia de protocolos de treinamento da atividade sentado-para-de-pé em mulheres idosas. Fisioter Bras. 2005;6(6):412-8.

28. Maruya K, Asakawa Y, Ishibashi H, Fujita H, Arai T, Yamaguchi $\mathrm{H}$. Effect of a simple and adherent home exercise program on the physical function of community dwelling adults sixty years of age and older with pre-sarcopenia or sarcopenia. J Phys Ther Sci. 2016;28(11):3183-8.

29. Han P, Kang L, Guo Q, Wang J, Zhang W, Shen S, et al. Prevalence and Factors Associated with Sarcopenia in Suburb-dwelling older chinese using the asian working group for sarcopenia definition. J Gerontol A Biol Sci Med Sci. 2016;71(4):529-35.

30. Tanimoto Y, Watanabe M, Sun W, Sugiura Y, Hayashida I, Kusabiraki T, et al. Sarcopenia and falls in communitydwelling elderly subjects in Japan: Defining sarcopenia according to criteria of the European Working Group on Sarcopenia in Older People. Arch Gerontol Geriatr. 2014;59(2):295-9.

31. Mortazavi Shati M, Eftekhar Ardebili H, Mohammad K, Dorali Beni R, Hassanzadeh Keshteli AS. Comparing the effects of group and home-based physical activity on mental health in the elderly. Int J Prev Med. 2013;4(11):1282-9.
32. Hamer M, Batty GD, Kivimaki M. Sarcopenic obesity and risk of new onset depressive symptoms in older adults: English Longitudinal Study of Ageing. Int J Obes. 2015;39(12):1717-20.

33. Byeon CH, Kang KY, Kang SH, Kim HK, Bae EJ. Sarcopenia is not associated with depression in Korean adults: Results from the 2010-2011 Korean National Health and Nutrition Examination Survey. Korean J Fam Med. 2016;37(1):37-43.

34. Hsu YH, Liang CK, Chou MY, Liao MC, Lin YT, Chen LK, et al. Association of cognitive impairment, depressive symptoms and sarcopenia among healthy older men in the veterans retirement community in southern Taiwan: A cross-sectional study. Geriatr Gerontol Int. 2014;14(Suppl 1):102-8.

35. Messier V, Hayek J, Karelis AD, Messier L, Doucet E, Prud'Homme D, et al. Anthropometric, metabolic, psychosocial and dietary factors associated with dropout in overweight and obese postmenopausal women engaged in a 6-month weight loss programme: a MONET study. Br J Nutr. 2010;103(8):1230-5.

36. Campos MTFDS, Monteiro JBR, Ornelas APRDC. Fatores que afetam o consumo alimentar e a nutrição do idoso. Rev Nutr. 2008;13(3):157-65.

37. Wang X, Shen W, Wang C, Zhang X, Xiao Y, He F, et al. Association between eating alone and depressive symptom in elders: a cross-sectional study. BMC Geriatr. 2016;16(19):1-10.

38. Vilar-Compte M, Martínez-Martínez O, Orta-Alemán D, Perez-Escamilla R. Functional limitations, depression, and cash assistence are associated with food insecurity among older urban adults in México City. J Health Care Poor Underserved. 2016;27(3):1537-54.

39. Carneiro R, Falcone E, Clark C, Del Prette Z, Del Prette A. Qualidade de Vida, Apoio Social e Depressão em Idosos : Relação com Habilidades Sociais. Psicol Reflex Crit. 2007;20(2):229-37.

40. Trombetti A, Reid KF, Hars M, Herrmann FR, Pasha E, Phillips EM, et al. Age-associated declines in muscle mass, strength, power, and physical performance: impact on fear of falling and quality of life. Osteoporos Int. 2016;27(2):463-71. 
41. Guimarães ACA, Scotti AV, Soares A, Fernandes S, Machado Z. Perception of quality of life and finitude of middle-aged adults and elderly practitioners and nonpractitioners of physical activity. Rev Bras Geriatr Gerontol. 2012;15(4):661-70.

42. Merquiades JC, Agra JHM, Albuquerque KMD, Costa RC, Navarro AP. A importância do exercício físico para a qualidade de vida dos idosos. Rev Bras Prescr Fisiol Exerc. 2009;3(18):597-614.
43. Maia FES, Moura ELR, Madeiros EC, Carvalho RRP, Silva SAL, Santos GR. A importância da inclusão do profissional fisioterapeuta na atenção básica de Saúde. Rev Fac Cienc Med Sorocaba. 2015;17(3):110-5.

44. Nascimento RG, Oliveira JSS, Ferreira LS, Santos ZNL, Cardoso RO. Fisioterapia gerontológica na atenção primária à saúde: uma experiência na região norte. Cienc Saude. 2013;6(3):222-8.

Received: 07/27/2018

Recebido: 27/07/2018

Approved: 02/03/2020

Aprovado: 03/02/2020 